\title{
CINEFILIAS AL MARGEN DE LA SALA DE CINE: HUELLAS DEL CINE Y LA TELEVISIÓN EN LA NOVELA ESPAÑOLA DEL SIGLO XXI
}

\author{
Carmen PEÑA ARDID \\ Universidad de Zaragoza \\ cpardid@unizar.es
}

\begin{abstract}
Mi biografía se podría reconstruir a través de esas placentas protectoras con nombres palaciegos, Dux, Elíseos, Pagoda, Coliseum, Rialto, Rex, Dome, Capitolio, Roxy, que a menudo se repiten de ciudad en ciudad, de continente en continente.
\end{abstract}

José María Conget, «Mi vida en los cines» (2013)

$\mathbf{P}$ elículas en las salas de cine

Quisiera recordar un hermoso y poco difundido mediometraje autobiográfico de Víctor Erice, titulado La Morte Rouge (Soliloquio) (2006) ${ }^{1}$, donde el cineasta recrea con documentos fotográficos, imágenes filmadas y el discurso de su propia voz la que recuerda como su primera experiencia del cine: cuando, en la España de 1946, teniendo él cinco años, fue con su hermana algo mayor a la sala del Gran Kursaal de San Sebastián para ver una película de las que el público llamaba «de miedo». El cineasta averigua el título del filme -La garra escarlata (The Scarlet Claw, Roy William Neill, 1944) $-^{2}$, revive su «atmósfera de pesadilla», así como la del decadente edificio del Kursaal, poblado ya de fantasmas cuando acogió las proyecciones de cine de su infancia, y da sentido a aquella experiencia personal de iniciación proyectándola en la historia colectiva (ligando el miedo de la aventura fílmica a la vivencia del dolor y el miedo de una sociedad devastada por las guerras), evocando sus efectos traumáticos (los terrores del niño, más allá de la pantalla) y su dimensión cognitiva: dando forma a las preguntas que comenzó a formularse entonces, no solo al contemplar ciertas formas del mal y de la muerte («que los hombres podían dar muerte a los otros hombres»), sino la misteriosa actitud de los espectadores adultos que, atentos a la pantalla y, a la vez, impasibles,

\footnotetext{
${ }^{1}$ Este filme-ensayo de 35 minutos de duración se realizó para ser exhibido en la exposición Víctor Erice/ Abbas Kiarostami. Correspondencias, organizada en 2006 por el Centre de Cultura Contemporània de Barcelona y la Casa Encendida de Madrid. En 2009, La Morte Rouge se editó en DVD, junto al cortometraje Alumbramiento. Las citas pertenecen al discurso de la voz en off del filme.

${ }^{2}$ Uno de los títulos del ciclo de películas que la Universal dedicó en los años 40 a las aventuras del detective Sherlock Holmes, interpretado por Basil Rathbone, con Nigel Bruce en el papel de Whatson. La acción transcurre en una aldea imaginaria del Canadá francés -llamada, como la película de Erice, La Morte Rouge-, donde Holmes investiga los crímenes de un actor que mata a sus víctimas degollándolas con una garra metálica.
} 
«parecían no verse afectados por las muertes que tenían lugar ante sus ojos», como si hubieran hecho un pacto -especula el narrador- o conocieran un secreto que el niño ignoraba y cuya revelación entrañaría para él la pérdida «de toda la inocencia del mundo» (Erice, 2006).

La Morte Rouge trata de la relación entre la pantalla y la vida, del aprendizaje del «pacto de la ficción» y del alumbramiento de un cineasta (Bergala, 2006: 14; Peña Ardid, 2016: 380). Pero también rinde homenaje a una forma de experiencia cinematográfica que conocieron varias generaciones de espectadores y espectadoras para las que el cine, además de «la forma suprema del entretenimiento» (Muñoz Molina, 2015:8), fue un medio de formación, estrategia de supervivencia y revulsivo, después, de la memoria (Marí, 2003: 63-65). Un tiempo, por otra parte, en el que las películas no estaban disponibles como en la actualidad, sino que, en palabras de Anne y Joachim Paech, eran «un acontecimiento que se producía exclusivamente dentro de las salas de cine», por lo que solo quedaban «a disposición de la memoria y unidas a la propia biografía» (2002: 229). Como rara vez las salas comerciales reponían títulos lejanos y anticuados, «una película estaba siempre unida a un determinado indicador temporal histórico de su rodaje y proyección en los cines» (2002: 230). Funcionando como la moda, sujetas a «la frágil existencia en la novedad»-de la que todavía se duele René Clair en 1970 (1974: 311)-, las películas pasaban enseguida a recordarse como ausentes (de ahí la posterior búsqueda cinéfila), mientras que «la sala y sus rituales» conferían continuidad a la experiencia del cine, vivida en una doble dimensión: como contacto con otro mundo alternativo al cotidiano y como un lugar de experiencias que los espectadores tienen de su propia vida. Muchos testimonios evocativos funden luego ambas vertientes en lo que los Paech llaman el «cine en la mente», donde «la historia del cine y la historia individual quedan inseparablemente unidas» (Paech, 231) ${ }^{3}$.

La narrativa española $-y$, por supuesto, la de los países hispanoamericanos- ha recreado ampliamente y con originalidad las vivencias ligadas a la frecuentación de las salas de cine como hitos de la biografía de los personajes o como escenarios de la trama (Marí, 2003). Desde la jocosa semblanza de una sesión de cine de barrio en La tournée de Dios (Enrique Jardiel Poncela, 1932/1998: 99-103) al entusiasmo con el que unas jóvenes modernas -aprendices de escritoras y artistasfrecuentaban el modesto cine Pardiñas en el Madrid de los años 20 (Barrio de maravillas, Rosa Chacel, 1975); desde la descripción de los rituales de «ir al cine» en grupo o en pareja (de novios) que plasman Entre visillos (Carmen Martín Gaite, 1958) o el cuento «Tarde en el cine» (Mercè Rodoreda, 1958), al

\footnotetext{
${ }^{3}$ Respecto al carácter efímero de las películas en las salas de cine, Anne y Joachim Paech mencionan como excepción los cineclubs, que ya disponían en los años 50 «de archivos cinematográficos y de modalidades especiales de distribución» (2002: 230), aunque cabría añadir el papel que desempeñaban las programaciones de los cines de reestreno y, al menos en España, los «de verano». La necesidad de prolongar el placer de las fugitivas películas se manifestó muy pronto, como se sabe, a través de la escritura. En 1915 aparecen las versiones noveladas de películas (ciné-romans) que ayudaban no sólo a una mejor compresión de los filmes, sino, como señalan Alain et Odette Virmaux, a prolongar sus efectos: «il favorise une sorte de réduplication, par l'imaginaire, des moments naguère apprécies; il introduit enfin la possibilité d'une réévaluation, à distance, de la satisfaction première» (1983: 18). Otra forma de recordar y recrear las películas en su ausencia eran las narraciones orales: «Cuando yo era niño - explica Muñoz Molina-, la gente, también los adultos, dedicaba mucho tiempo y esfuerzo a contar películas, y así, un producto de Hollywood, hecho y difundido gracias a las tecnologías más costosas, se convertía en lo más primario y lo más humilde, un cuento contado en voz alta en un corrillo» (2015:8). Recuérdese la importancia del relato fílmico «hablado» (contaminado por la tradición oral) en El beso de la mujer araña (Manuel Puig, 1976) o en La contadora de películas (Hernán Rivera, 2009).
} 
universo mágico y fascinante de la sala-pantalla-película(s) que cobija para siempre el tiempo de la infancia («El niño lobo del cine Mari», José María Merino, 1982), modela la sentimentalidad adolescente (El día que murió Marilyn, Terenci Moix, 1970; Todas las mujeres, José María Conget, 1989) y deriva en pasión cinéfila o vampírica cinefagia (La gran ilusión, Manuel Sánchez-Ostiz, 1989), sin olvidar el contraste dialéctico que la narrativa de Juan Marsé -y, en especial, El fantasma del cine Roxy (1985)- ha erigido entre la esfera del mito, el glamour y los sueños de la pantalla (alimentada por las ficciones de Hollywood), y una realidad áspera y degradada en la Barcelona de postguerra que describe el autor (Kim, 2006: 188-193).

En algunas novelas recientes -sobre todo si miran al pasado-, la experiencia de «ir al cine» todavía puede aparecer forjando las señas de identidad de ciertos personajes. Como el adolescente que, en El viento de la luna (Antonio Muñoz Molina, 2006), da cuenta de su vivir y el de su entorno en la Mágina del final de los años 60, anhelando ya la compra del aparato de televisión que le permitirá ser testigo en casa y en directo del alunizaje de la nave Apolo XI. Pero a la vez es asiduo del «Ideal Cinema»-lo son las tres generaciones de su familia- y recuerda como un hito la ocasión singular en que, a los siete u ocho años, su padre lo llevó al cine para ver una película antigua -Los hermanos Marx en el oeste- que el progenitor había visto «durante la guerra» (2006: 196) ${ }^{5}$. Cuenta que a él le «alarmaban aquellos personajes apresurados y estrambóticos» y que, al principio, no entendía que su padre riera «como no solía hacerlo nunca en casa», hasta que miró la película con la misma atención que el padre y empezó a reír «tan sonoramente como él, como el público entero del cine que aplaudía y silbaba a nuestro alrededor» coreando las órdenes «dementes» en la escena de la destrucción del tren. «Durante mucho tiempo - concluye- nos acordamos él y yo de aquella noche singular en la que habíamos estado solos en el cine, y cuando nos contábamos de nuevo el uno al otro los pormenores de la aventura del tren destrozado a hachazos, el grito de más madera tenía algo de contraseña secreta entre nosotros» (2006: 198) ${ }^{6}$.

Una pieza ejemplar del tema es sin duda el relato de José María Conget, «Mi vida en los cines», publicado en La mujer que vigila los Vermeer (2013). La vinculación de este escritor con el cine, tantas veces plasmada en su obra literaria, cristaliza aquí en un personaje que afirma poder reconstruir toda su biografía «a través de esas placentas protectoras con nombres palaciegos: Dux, Elíseos, Pagoda, Coliseum, Rialto, Rex, Dome, Capitolio, Roxy, que a menudo se repiten de ciudad en ciudad y de continente en continente» (2013: 83). Teje así, de sala en sala, el tapiz de una trayectoria vital e

\footnotetext{
${ }^{4}$ Habría que recordar, por supuesto, otros títulos relevantes como «La vieja del cinema» (Vicente Blasco-Ibáñez, $O C$, 1961); «La oficina» (Carmen Martín Gaite, 1954) ; La vida perra de Juanita Narboni (Ángel Vázquez, 1976/ 2008: 134155); Beltenebros (Antonio Muñoz Molina, 1989), Escenas de cine mudo (Julio Llamazares, 1994) o Una vuelta por el Rialto (Marcos Ordóñez, 1994).

${ }^{5}$ El filme Go West fue dirigido por Edward Buzell en 1940 y no se estrenó en España hasta 1944. La idea de que el padre del protagonista vio la película de niño durante la guerra mientras su propio padre combatía en el frente puede ser una licencia poética del autor o una constatación de las frecuentes inexactitudes de la memoria personal y familiar.

${ }^{6}$ Este episodio - de cierta extensión en la novela- remite, por un lado, a una cultura cinematográfica transmitida intergeneracionalmente $y$, por otro, a la «intangible» comunicación emocional que la visión compartida de las películas ha propiciado, ensanchando en ocasiones las fronteras más rígidas de lo decible/visible en la esfera cotidiana. El cine en la sala sitúa a los/as espectadores en un marco social que trasciende el círculo familiar (o privado) televisivo.
} 
intelectual en varias etapas que recorre cines de provincia y cines cosmopolitas, tugurios y templos suntuosos; que deja constancia -con ironía-de las experiencias vividas en estas sesiones y también de las que nunca tuvo, a la vez que da forma a una historia personal del cine que incluye títulos señeros, prohibidos y largamente buscados. Su itinerario acoge personajes esenciales: figuras iniciáticas, amigos cómplices y la mujer compañera con la que, en distintos tiempos y lugares, compartió su afición. Hasta que llega un día en el que se da cuenta de que hace tiempo que sólo compra una entrada en la taquilla porque va solo a ver todas las películas: «Y lo peor estaba por venir: también hubo una noche en la que era yo el único espectador en un anfiteatro vacío» (2013: 119). No es «la muerte de las películas» lo que teme el protagonista de este relato elegíaco, sino «la desaparición de los templos donde se oficia la ceremonia de su proyección» ya que, con ella, se disuelven en la nada grandes fragmentos de la propia existencia: «Todos los cines, por fin, habían cerrado ¿En qué pozo sin fondo se hundieron las películas de la vida? ¿Dónde estaban los regocijados amigos con los que tantas risas, dónde mis hermanos, mis hijos? ¿Dónde el rostro de la mujer que amé?» (2013: 120).

El declinar del disfrute del cine en las salas, sobre todo en los países occidentales, trae la melancolía del ubi sunt y quizá una nueva emergencia del tema en la literatura ${ }^{7}$. Citaré, como último ejemplo, el relato «Sesión continua» (2010) de un escritor, Luis Manuel Ruiz, más joven que los anteriores. En él, una voz narradora, impersonal al comienzo, presenta al protagonista (Neira) en una situación límite: desangrándose en una acera, tras ser tiroteado por la policía, y viendo desfilar las imágenes que resumen momentos cruciales de su vida; especialmente «la infinidad de salas de cine que ha visitado a lo largo de [muchos] años de clandestinidad y huida» (2010: 168) dedicados a la resistencia antifranquista. Una vez al mes, siempre el día veintidós, el hombre iba a una de las salas convenidas [Excelsior, Alvear, Apolo, Pathé], generalmente de sesión continua, ocupaba una localidad en la fila veintidós, junto al pasillo, y aguardaba viendo la película a que se produjera el contacto. Entre filmes vistos repetidas veces -«se había contagiado del blanco y negro de los rostros de la pantalla» (2010: 180) - y citas clandestinas se enamora de una mujer que es la narradora de la historia y la que lo traiciona para salvar a su propio padre. Ella testifica su muerte invirtiendo el paso de la moviola para cerrar el relato con las últimas palabras de Neira, el «ultimo» del grupo de resistentes que, al pedir la muerte, renuncia a la vez a la lucha y a su condición de espectador:

Se muere en este justo instante, ahora que abrazo a papá..., se muere sobre la acera después de los siete disparos, después de salir del cine y levantar los brazos, después de exigir con un grito la mirada de las pistolas: yo soy el último, matadme, ya no quiero ver más (2010: 193).

\section{El «viejo» cine y la deslocalización audiovisual}

Con el título «cinefilias al margen de la sala de cine» no pretendo adoptar en este análisis ninguna actitud nostálgica. He querido aludir, eso sí, a la deslocalización actual del consumo cinematográfico

\footnotetext{
${ }^{7}$ Recordemos que, en la narrativa de los años 90, es cuando cobran protagonismo los cines abandonados (Beltenebros) o derribados («El niño lobo del Cine Mari»; Un paseo por el Rialto), con el antecedente de la película de Giuseppe Tornatore, Cinema Paradiso (1988) o, más recientemente, Goodbye Dragon Inn (Tsai Ming-Liang, 2003),
} 
(Quintana, 2017: 16) y, en términos más amplios, a los cambios que se han producido en las últimas décadas en el dominio del audiovisual y en el lugar que ocupa el cine en el del arte y la cultura. Entre esos cambios no es menor el que ha supuesto la reconfiguración del modo de recepción y difusión de las películas, visibles y visionadas hoy en una gran variedad de pantallas, soportes y circuitos de programación que mantienen viva la exhibición pública (salas de cine, filmotecas, festivales, museos) aunque con un dominio creciente del visionado doméstico en múltiples dispositivos (televisión, HomeCinema, reproductores multimedia, pantallas conectadas a la red virtual de internet y a sus plataformas online). Con el desarrollo de las tecnologías digitales, el concepto mismo del audiovisual como sistema de expresión se ha transformado, remitiendo a «un modo de creación que unifica un gran flujo de imágenes que reúne el cine, la televisión, el vídeo o internet» (Quintana, 2011: 167). En este sentido, el proceso de la deslocalización audiovisual, sobre el que reflexiona Ángel Quintana, expresa no sólo la ruptura de las fronteras que singularizaban esas imágenes y sus circuitos de difusión, sino la «confusión y clonación de formatos» ${ }^{8} \mathrm{y}$, en último término, la hibridez y desjerarquización características del ciberespacio - gran depósito de la cultura digital- en el que las imágenes profesionales conviven con la producción amateur, el documento de alta calidad «con planos rodados en pequeño formato desde videocámaras, teléfonos móviles, o con videoconferencias grabadas desde una webcam» (2011: 180) que inundan los videologs, YouTube o cualquiera de los «Social Media».

El cine ocupa desde hace tiempo un lugar menor, aunque todavía prestigioso, en ese mar audiovisual que ha proliferado en la era de la cultura-red pantallizada ${ }^{9}$, en la que, como observó Régis Debray, «nuestros ojos ignoran cada vez más la carne del mundo» (1995: 97). De un «absolutismo del Audiovisual» («iay!, demasiadas imágenes pueden aniquilar la imagen misma») habla Víctor Erice al denunciar los desajustes que produce «esa industria pesada de nuestro tiempo que se ha dado en llamar Comunicación»(2007: 11). Y no solo los grandes medios: la hipertrofia icónica -y texto/audio icónica-también domina, como apuntábamos, las tecnologías horizontales y democratizadas de la red; tecnologías que, como observa Remedios Zafra, nos incluyen como participantes en sus bases de datos y movilizan la hipervisibilidad, la autorrepresentación como tema (a través de videos, fotografías): «Ser vistos no es ya una posibilidad en el mundo conectado, ser vistos es una exigencia, una característica a la que los humanos deberán habituarse en el futuro cercano» (2015: 43). Incluso mediante el espionaje cibernético que infecta la cámara del ordenador; un tercer ojo indiscreto del que se sirve Isaac Rosa en varios fragmentos de su novela La habitación oscura (2013) que, con el título

\footnotetext{
8 «En el modelo clásico, las películas estaban pensadas para las salas y las series para la pequeña pantalla. En los sesenta, el espectador veía en la pantalla de Cinerama La conquista del oeste y en blanco y negro los episodios de Bonanza. Actualmente, una parte del cine transita por las mismas pantallas que las series. En una plataforma como Netflix podemos llegar a acceder a I Don't Feel at Home in this World Anymore, de Macon Blair, ganadora del festival Sundance 2017, o a la esperada Mindhunter, producida por David Fincher. Este fenómeno provoca confusión y clonación de formatos. El cine intenta acercarse a las series y las series al cine», modificándose a la vez los conceptos de autor, puesta en escena o guion (2017: 16).

${ }^{9}$ Vid. el concepto de pantalla global que formula el filósofo francés Gilles Lipovetsky, para quien se ha pasado, en unas décadas, de la pantalla espectáculo única e insustituible -cine- al régimen de la pantalla comunicación, omnipresente y multiforme, planetaria y multimediática (2009:14).
} 
«Rec», se alternan de forma enigmática entre los capítulos que desarrollan la historia principal. Restringido el campo de visión al marco de la pantalla, el ejercicio de ékfrasis se recrea en los detalles y en la banalidad de la escena de la vida privada que se nos «da a ver», cuyo interés reside en que es «auténtica», «instantánea», atrapada sin autorización; una escena, por otra parte, que en este ejemplo hace un retrato cabal del nuevo sujeto humano conectado a la red y que sugiere la reversibilidad de la mirada:

REC

El encuadre muestra el busto, lo que los fotógrafos llaman un plano medio corto, algo más abierto que un primer plano: el límite inferior del rectángulo corta el pecho, el rostro queda en el centro de la pantalla y por encima hay aire. El hombre apenas mueve los hombros o la cabeza, y por sus pequeñas sacudidas adivinamos cuándo adelanta las manos para teclear o manejar el ratón.

Sus manos, de dedos largos y huesudos, y la piel con motas amarillentas de vejez, solo aparecen en la pantalla cuando se las lleva a la cara: un dedo que rasca la nariz o hurga en su interior, la palma que frota la incipiente barbilla..., la uña que levanta las escamas en el cuero cabelludo o hurga entre los dientes.

[...] A su espalda una librería deja ver cuatro baldas. Dos están llenas de libros, es fácil leer el título de la mayoría, no necesitamos un zoom...

Como la cámara está insertada en el borde superior de la pantalla, ante nosotros, su mirada se dirige ligeramente hacia abajo. En el cristal de las gafas se refleja el colorido de las páginas visitadas, con un aumento podríamos reconocer el contenido. Sus pupilas se deslizan de izquierda a derecha en el sentido de la lectura [...] A veces su mirada transmite desinterés, fastidio; otras se concentra componiendo una máscara de gravedad.

También hay sonido: escuchamos el tecleo monótono, el clic repetido del ratón, una tos, un brusco sorber de la nariz... Y la música: oímos la que él escucha...

El hombre bosteza, toma el vaso, apura el resto, se pone en pie y sale de escena hacia la izquierda. Queda el plano fijo del respaldo verde de la silla... Dos minutos de cuadro inmóvil, donde suena para nadie el piano, hasta que regresa, se sienta de nuevo...La mano vuelve al ratón, la otra entretiene un dedo en la oreja, entorna los ojos, mira fijamente. Nos mira fijamente: como si fuera él quien nos observa a nosotros (Rosa, 2013: 39-41) ${ }^{10}$.

$$
* * *
$$

El panorama anterior someramente expuesto ha suscitado numerosas reflexiones desde la sociología, la comunicación, la estética, la crítica del cine y de la literatura que no cabe desarrollar aquí aunque atañen al contexto de nuestro análisis. ¿Qué lugar ocupa el cine en la iconosfera contemporánea y cuál es su relevancia cultural ? $^{11}$ ¿Hasta qué punto la producción masiva y democratizada de imágenes permite delimitar un grado cero, un «uso común» del lenguaje audiovisual

${ }^{10}$ La obscenidad de la operación de espionaje se hace más explícita en el último fragmento, que graba a un individuo mientras se masturba ante la pantalla del ordenador, visitando páginas de pornografía. El narrador emplea en sus descripciones técnicas que recuerdan el objetivismo conductista.

${ }^{11}$ Queda lejos el debate sobre «la muerte del cine» que proliferó con la celebración del centenario en 1995 y del que se hicieron eco varios capítulos del volumen XII de la Historia General del cine. El cine en la era del audiovisual, (Palacio y Zunzunegui, 1995). Román Gubern constataba entonces «su pervivencia como modelo expresivo fundacional y matricial irrenunciable para el gran magma omnipresente de la cultura audiovisual contemporánea» (1995: 309). Años después, Lipovetzky reiteraba su carácter de matriz «en la cultura hipermoderna, algo que sólo se puede llamar espíritu cine y que atraviesa, riega y nutre las demás pantallas...Cuanto más compiten con él o lo sustituyen la Red, la televisión, los videojuegos y los espectáculos deportivos, más fagocita su estética esencial áreas enteras de la cultura de la pantalla» (2009: 25). Tras experimentar cambios que han afectado a todos sus dominios, el cine mantiene una saludable vitalidad aunque su sea lugar periférico- y las preguntas que se formula la crítica tienen mucho más que ver con su función estética, sus vínculos originarios con lo real y el modo en que puede contribuir a repensar la imagen en un mundo de imágenes (Quintana, 2011: 37 y 193). 
-no artístico-, como el que buscaban los formalistas rusos, para definir el cine como arte? ${ }^{12}$ En cuanto a la «vieja» literatura (la que no es hipertextual ni transmedia), ¿cómo se hace eco, en sus temas y elaboración estética, del flujo informativo y comunicativo cibernético, del proliferante paisaje textoaudio-visual y de la hipermediación de los medios que trastoca los conceptos de realidad y ficción o la credibilidad del yo en el discurso? ¿Qué papel sigue teniendo el cine, como referente cultural y artístico, en la narrativa española de los últimos años? ¿Cómo se conecta con otras herencias culturales y otros modelos más a la moda, como la teleficción, los video-juegos, los chats y videos de YouTube, formas más acordes con la realidad que envuelve al lectoespectador sobre el que teoriza Vicente Luis Mora (2011)?

\section{Factores del impacto intermedial. Cine y Televisión en la literatura}

Para responder a estas preguntas no voy a servirme de las clásicas distinciones generacionales entre grupos de escritores y escritoras. Aunque la narrativa española de los últimos años ha visto aflorar una generación «mutante» $\mathrm{o}$ «afterpop», cuya estética responde de modo explícito al exceso simbólicomediático del que venimos hablando (Fernández Porta, 2007; Mora, 2011:71-82), lo cierto es que, con diferencias de grado, eso sí, la exhibición cinéfila y la apertura a la esfera mediática está presente en un gran número de autores de diversas edades y orientaciones estéticas: desde Enrique Vila-Matas, Javier Marías, Antonio Muñoz Molina a Javier Cercas, Ignacio Martínez de Pisón, Marta Sanz, Isaac Rosa o a los más «jóvenes» Berta Marsé, Manuel Vilas, Agustín Fernández Mallo, Patricia Esteban, Mario Cuenca Sandoval, entre otros. Por ello prefiero tomar en consideración un modelo más complejo que tenga en cuenta algunos de los factores que, históricamente, han condicionado la impronta del cine en la literatura y los modos de manifestaste. Entre ellos: 1) el interés que ha despertado el cine en muchos escritores y la importancia que adquiere en su formación (en paralelo, a veces, con la literatura); 2) La evolución del propio lenguaje cinematográfico (como repertorio de obras, estilos, procedimientos y convenciones), su relación con otras artes y su progresiva legitimación en la escena cultural, moviéndose en una tensión entre lo culto y lo popular que ha permitido tanto apreciaciones mitómanas como intelectuales. 3) La accesibilidad a las imágenes mediante circuitos de exhibición complementarios y nuevos dispositivos tecnológicos; 4) Los principios estéticos a los que se acoge la creación literaria receptora de la huella del cine, en la medida en que orientan el tipo de diálogo intertextual o la función y significado que adoptará un recurso ajeno en el nuevo contexto que lo $\operatorname{acoge} \mathrm{e}^{13}$.

Los dos primeros factores marcarían bien el el contraste entre el estatus del cine y el del medio televisivo que, en el caso de España, alcanza su hegemonía en el espacio audiovisual desde el final de

\footnotetext{
${ }^{12}$ Sobre los planteamientos de B. Eichembaum y Juri Tinianov, véase Carmen Peña Ardid (2009: 63-65).

${ }^{13}$ Así se explica, por ejemplo, que la incorporación a la novela de nuevos ángulos de visión, barridos de la mirada y efectos de montaje «propios del cine» sirviera para renovar la mimesis realista en la narrativa del medio siglo -Sánchez Ferlosio, Fernández Santos, Martín Gaite-y, en cambio, esas mismas técnicas cinematográficas permitieran subrayar la subjetividad del punto de vista o «desrealizar» la representación en las novelas «experimentales» de José María Guelbenzu o Juan Goytiloso.
} 
los años 60 (El viento de la luna testimonia en la ficción -creo que por primera vez- la adquisición del electrodoméstico en los hogares de clase media). A pesar de su influencia y omnipresencia -o por ello mismo-, la televisión ha sido considerada en los medios intelectuales como un «mal objeto» (Palacio, 2010; Fernández, 2014: 83-99) y carece -todavía- de verdadera legitimación cultural, por lo que no ha de extrañar que su eco en la literatura y, en concreto, en la novela española, haya sido hasta hace poco muy escaso. Cargada de connotaciones negativas aparece en Reivindicación del conde Don Julián (1970), de Juan Goytisolo, donde el «ojo ciclópeo del artefacto» es el vehículo de la propaganda franquista, templo de la sociedad de consumo y objeto hipnótico para una audiencia alienada que se deja seducir por la voz en off del «oráculo» (Goytisolo, 1970: 89-127) ${ }^{14}$. En El cuarto de atrás, de Carmen Martín Gaite (1978), las imágenes que retransmite televisión tienen otra trascendencia: «dan testimonio» y credibilidad a la muerte de Franco, cuyo entierro contempla la narradora, no en su domicilio - pues no tiene televisión-, sino en un bar próximo donde se congrega una representación bulliciosa de la sociedad española y donde va a ser consciente, contemplando la llegada al Valle de los Caídos y la aparición de Carmencita Franco en el cortejo, del largo bloque de tiempo vivido bajo el «reinado» del Caudillo (1978: 133-138). El documento televisivo también es un referente irreemplazable en la larga meditación que elabora Javier Cercas sobre el aislamiento político de Adolfo Suárez cuando se produjo el intento de golpe de estado del 23-F (Anatomía de un instante, 2009). A diferencia de El cuarto de atrás, las imágenes del acontecimiento no son vistas fugazmente sino en una grabación que posibilita la detenida ékfrasis:

La imagen congelada, muestra el hemiciclo del Congreso de los Diputados desierto. No, la imagen está congelada, pero el hemiciclo (mejor dicho: su ala derecha, que es la que en realidad muestra la imagen), no está desierto: Adolfo Suárez permanece todavía sentado en su escaño azul de presidente, todavía estatutario y espectral. Aunque ya no está solo: han transcurrido dos minutos desde la entrada del teniente coronel Tejero en el Congreso y junto al presidente, a su derecha, se sienta el general Gutiérrez Mellado; más a su derecha todavía, tres ministros [...] Una luz acuosa, escasa e irreal envuelve la escena [...]

Que de repente se descongela: la descongelo. Ahora, en el silencio crepitante y atemorizado del hemiciclo, los guardias civiles deambulan por el hall... (2009: 175) $)^{15}$

La posesión de las imágenes permite escudriñarlas, perseguir sus signos menos visibles ensanchando su duración. Son imágenes históricas que están en la memoria de muchos ciudadanos, pero también son públicas y accesibles para su visionado en internet. ¿Pertenecería su descripción a un modo antiguo de literatura? Vicente Luis Mora subraya precisamente las diferencias entre una literatura (tardo)modernista que todavía recurre a la descripción de lo que el lector puede ver (cita el caso de Fiebre y lanza (2002), de Javier Marías) y la de «los actuales autores pangeicos [que] se limitan

\footnotetext{
${ }^{14}$ Sobre la paródica referencia al protagonista de la serie de televisión española El Séneca, de José Ma Pemán, vid. Luis Miguel Fernández (2014: 93). En cuanto a la incorporación del discurso televiso en otras novelas de Goytisolo -Las virtudes del pájaro solitario (1988) o La cuarentena (1991)-, véase Annie Bussière-Perrin (1998: 90-104).

${ }^{15}$ La tecnología del vídeo ya supuso, como observa bien José Antonio Pérez Bowie, una transformación radical de las condiciones de lectura del filme permitiendo «una serie de operaciones como la parada de imagen, las vueltas atrás o los saltos hacia adelante que lo asemejan a la lectura literaria» (2008: 182-183). Y ello tuvo su repercusión en el modo de hacerse presente el cine en la literatura ya que la evocación detallada de escenas no era nada frecuente cuando las películas solo estaban en la memoria. Un ejemplo extremo del cambio es la novela Cinéma (1999), de Tanguy Viel, en su intento de contar con palabras el filme de Joseph Mankiewicz Sleuth (La huella, 1972).
} 
simplemente a incluir la ilustración o la fotografía, sin acompañarla de descripciones; dan por supuesto que las imágenes hablan por sí solas. En realidad -añade- todo podría provenir de una equivocación conceptual: pensar que el texto y la imagen son cosas diferentes» (2011: 62-63). Sin entrar ahora en un debate milenario, no hay duda de que combinar imagen y texto por simple yuxtaposición (o como enlace a una página web), dejando abierta la interpretación del receptor/a, daría pie a una propuesta estética bien distinta a la buscada por Javier Cercas cuando se enfrenta a «una imagen irreal: la escena de una españolada recién salida del cerebro envenenado de clichés de un mediano imitador de Luis García Berlanga» (2011: 14).

Si continuamos nuestro recorrido, en Carreteras secundarias (1996), de Ignacio Martínez de Pisón, se muestra el papel aglutinador de la televisión como compendio de los iconos mediáticos que alimentan la imaginación de un adolescente en los años previos a la muerte de Franco (con héroes de la ciencia mezclados con mitos eróticos y héroes de series de ficción). Y es un hallazgo el protagonismo que, al comienzo de la novela de Javier Marías, Mañana en la batalla piensa en mí (1994), adquiere el televisor que emite en horario nocturno películas clásicas en blanco y negro -en este caso, Recuerdo de una noche (Mitchell Leisen, 1940)- que miran distraídamente un varón aturdido y un niño desvelado que todavía ignora la muerte de su madre.

De todos modos, solo en la obra de los escritores y escritoras nacidos a partir de los 70 se utilizan -aunque sea paródicamente y con actitud más o menos crítica- las estrategias discursivas televisuales, sus diferentes géneros - del reality show a las comedias de situación- o su retórica expresiva convertida en base de la ficción literaria, como ocurre en los cuentos reunidos en Risas enlatadas, de Javier Calvo (2001) o en la excelente pieza metaficcional de Berta Marsé «Los Pons Pons» (2009) ${ }^{16}$. No es ajena a esta atención el reciente cambio que se ha producido en la valoración cultural, ya no de la televisión como medio, sino de lo que acertadamente Concepción Cascajosa llama «la cultura de las series». Series «de culto» cuya narrativa se ha hecho más densa y compleja -en estrecha interacción con el cine, como vimos-, pero que viven además

[...] un proceso de legitimación resultado de una combinación de factores institucionales, socioeconómicos y tecnológicos. Esto no significa que ahora los espectadores vean más series de televisión, que históricamente han sido uno de los productos predilectos del medio, sino más bien que se generan más discursos sobre series, se han consolidado prácticas culturales relevantes a su alrededor y grupos sociales de estatus medio-alto las han adoptado dentro de sus rituales de consumo (2016: 12).

Buena muestra de este culturalismo es la novela Los muertos (2010), de Jorge Carrión, donde personajes reales y ficticios forman parte de la trama distópica de una serie de televisión que va contando un narrador-cámara, cuyos capítulos y «temporadas» son objeto del comentario crítico («Reacciones») de especialistas que reflexionan sobre su significación. Ocurre, sin embargo, que este modo de concebir una novela -combinando distintos tipos de discurso- no es tan ajeno a la práctica de otros escritores. Por ejemplo, Boxeo sobre hielo (2007), la primera novela de Mario Cuenca

\footnotetext{
${ }^{16}$ Otro de los cuentos que componen el libro Fantasías animadas, titulado «El bebé de Rosemary», es un curioso «remake» de la película La semilla del diablo (Roman Polanski, 1968).
} 
Sandoval, incluye una larga disertación sobre cine a cargo de un personaje que el protagonista ha conocido en un videoclub ( «La conferencia de Salim sobre la evolución de los atributos vampíricos en el cine de terror») Y en Los dos hemisferios, del mismo autor, la inspiración en el Hichcock de Vértigo se subraya -por si al lector/a no le quedan claros los paralelismos- incorporando fragmentariamente el ensayo de Eugenio Trías: «Vértigo y pasión».

Quisiera concluir precisamente comentando algunas de las formas más novedosas que adopta la huella del cine en la narrativa actual y que ponen de manifiesto una profunda asimilación de su herencia cultural y el apoyo que proporciona -junto a la tradición literaria muchas veces-a la hora de dar sentido a las experiencias humanas.

\section{Intertextualidad metaficcional}

Tomar el argumento una obra, o alguno de sus motivos, como espejo en el que se refleja la trama de otra es un recurso de gran tradición interliteraria e intermedial. Habría que rastrear en este sentido el impacto de películas carismáticas como 2001: Una odisea del espacio, Blade Runner o Matrix en la obra de Jorge Carrión, Vicente Luis Mora o Fernández Mallo. También la trama de Vértigo (Alfred Hitchcock, 1958) -con la parafernalia de motivos en torno a la fascinación masculina por una bella mujer casada, su irreparable pérdida y el afán de «reconstruirla» en otra que oculta un secretoreaparece como una obsesión en novelas tan distintas como Un buen detective no se casa jamás (2012), de Marta Sanz (que remite a ella desde la portada), Así empieza lo malo (Javier Marías, 2014) o Los dos hemisferios, de Mario Cuenca Sandoval (2014).

Pero invita a mayores reflexiones Soldados de Salamina (Javier Cercas, 2001), novela autoficcional que propone una memoria colectiva de la guerra civil de carácter cultural asentada en la imagen de un tipo de héroe -masculino- que tiene una gran deuda con las narrativas heroicas y crepusculares de John Ford. El título de uno de los capítulos «Cita en Stockton» evoca como espacio simbólico la ciudad californiana en la que transcurre la acción de la película de John Huston, Fad City (Ciudad dorada, 1972), donde sobreviven seres derrotados y aspirantes a héroes del boxeo. Esta ciudad «atroz y sin oportunidades», según dice Roberto Bolaño en la novela, se equipara a Dijon y a la residencia de ancianos, antesala de la muerte, en la que reside Miralles, el soldado republicano que Cercas identifica como «el hombre que no mató a Sánchez Mazas»; perdió la guerra civil pero salvó anónimamente la civilización y la democracia. No es difícil relacionar algunos motivos de la novela con el filme de John Ford El hombre que mató a Liberty Valance (1962), donde el periodista que quiere «saber la verdad» del pasado de labios del senador Ransom Stoddard (James Steward) acaba afirmando que -entre la historia y la leyenda- se imprime la leyenda. También Javier Cercas propone a los lectores aceptar la leyenda de los héroes que, en su viaje final en tren, cree ver reflejados en el cristal 
de la ventanilla avanzando por el desierto (como John Wayne en Ford Apache veía reflejados en el cristal a los soldados que han luchado heroicamente).

\section{Referentes fílmicos: homenaje, erudición y ensayismo cinéfilo}

La fuerza del mito persiste en otras novelas. Arturo Zarco, el detective bisexual que protagoniza los relatos policiales de Marta Sanz, da rienda suelta a su imaginación en Un buen detective no se casa jamás, (2012) imaginando unos mundos ficcionales habitables quizá mucho más gratos que los que le ofrece su entorno:

Viviría para siempre dentro del decorado de una película de Fritz Lang. Dentro de un cuadro que forma parte del sueño de un hombre insignificante: en el apartamento que se adivina -yo lo adivino porque me da la gana- detrás del sillón donde Joan Bennett se recuesta para magnetizar a Edward G. Robinson a través de la luna de un escaparate. Podría vivir también dentro del tecnicolor de Moonfleet... Podría vivir bailando en Brigadoon con Cyd Charisse...O en el decorado de una comedia musical de Vicenti Minelli Viviría entre la luz y la sombra, los movedizos reflejos del agua en la piscina, la insinuación de la pantera: Simone Simon - más turbia que la Tierney- muta en felino y, temerosa de que su excitación pinche y desangre -res abierta en canal- al único hombre que ama, cierra cautelosamente su dormitorio. Podría, incluso, vivir en la calle donde habita Marnie... Mamá copula con los marineros - escucho el lamento del jergón- y no soporto ver, sobre el blanco, el rojo.

Viviría dentro de cualquier fotograma en el que apareciera George Sanders: viviría en Rebeca [...] En la casa donde se rodó La semilla del diablo yo dormiría en la cuna de los doseles negros... Y, que recuerde por hoy, podría vivir en el restaurante de una película de Chabrol...

Si Paula estuviera al teléfono me gritaría: «Mitómano, mitómano, mitómano, al ritmo de una locomotora. Igual que la de Bringas cuando dice «Puta, puta, puta» mientras su sirvienta se aleja amancebada para siempre con un hombre rico (2012: 122-124)

Es la acumulación de referencias lo que sorprende ¿Se trata de un homenaje al cine clásico? ¿Es la exhibición erudita ante un lectorado también sabio pero al que hay que sorprender? ¿Es el peso de toda una tradición que siente un «detective consciente»? Si en la narrativa del siglo pasado, la referencia a una película buscaba satisfacer un horizonte de expectativas, una complicidad con el lector al que se daban pistas indirectas para su identificación esperando que buscara el sentido que la ligaba a la ficción novelesca, en los textos pos-pos-modernos hay auténticos alardes de erudición cinematográfica que encajan en una narrativa que combina ficción, memoria y ensayo, y que tal vez confía en las posibilidades de consulta en internet. En Daniela Astor y la caja negra (2013), de Marta Sanz, los capítulos dedicados a la descripción de los documentales críticos que elabora el personaje de Catalina Griñán son toda una lección sobre las películas de destape del tardofranquismo y la Transición, la Escuela de Barcelona (sobre todo, Vicente Aranda), los subgéneros del fantaterror... Al final de la novela se ofrece una lista de páginas web donde se pueden localizar los artículos e imágenes mencionadas.

Algo similar sucede en Aire de Dylan (2012), de Enrique Vila-Matas y en Así empieza lo malo de Javier Marías (2014). La exhibición de conocimientos cinéfilos se justifica en esta novela por el medio en el que se desarrolla la trama y la investigación, en la que se ve envuelto un joven de 23 años que ejerce como ayudante-secretario de un director de cine. Hay alardes eruditos sobre actores «secundarios», aunque míticos, como Jack Palance, sobre las producciones de Jesús Franco -tío del 
autor-sobre escándalos de Hollywood. Pero, ¿qué pensar de la descripción del fino bigote que luce uno de los personajes, Eduardo Muriel «como si se lo hubiera dejado crecer cuando Errol Flynn era un modelo». Pero no es suficiente esta referencia:

$\mathrm{Su}$ aspecto era como si inconscientemente se hubiera quedado adherido a la imagen de los galanes de cuando él era niño y adolescente; en los años treinta y cuarenta, no sólo a la de Errol Flynn (por antonomasia, y con quien compartía la sonrisa fulgente), sino a los actores hoy mucho más nebulosos como Ronald Colman, Robert Donat, Basil Rathbone, incluso David Niven y Robert Taylor, que duraron más tiempo, tenía un aire a todos ellos pese a que entre sí fueran distintos. Y, puesto que era español, en algún momento recordaba a los más tostados, aún más diferenciados y exóticos Gilbert Roland y César Romero, sobre todo al primero, cuya nariz era grande y sin curva como la suya (2014: 21).

Estas figuras - polvo de estrellas- todavía arrastran un significado; son modelos de una representación del pasado tal vez olvidada pero que el depósito cultural de internet quizá ayude a recuperar.

\section{Referencias bibliográficas}

Bergala, Alain (2006): «Erice-Kiarostami: los caminos de la creación», en Alain Bergala y Jordi BALló, dirs., Erice-Kiarostami. Correspondencias. Barcelona, Centre de Cultura Contemporánea de Barcelona e Instituto de Ediciones de la Diputación de Barcelona, pp. 10-20. Blasco IBÁLEZ, Vicente (1999): «La vieja del cinema», OC [1961], en De Baroja a Buñuel. Cuentos de cine. Madrid, Clan Editorial.

BusSIÈRE-PERRIN, Annie (1998). Le théâtre de l'expiation. Regars sur l'oeuvre de Juan Goytisolo. Montpellier, Editions du Cers.

CAlvo, Javier (2001): Risas enlatadas. Barcelona, Randon House.

CARRIÓN, Jorge (2010): Los muertos. Barcelona. Galaxia Gutemberg.

CASCAJOSA VIRINO Concepción (2015): La cultura de las series. Barcelona, Laertes.

CERCAS, Javier (2009): Anatomía de un instante. Barcelona. Mondadori.

CHACEL, Rosa (1976): Barrio de maravillas. Madrid, Castalia, 1993.

ClAIR, René (1970): «El tiempo que no pasa», en Cine de ayer, cine de hoy. Valencia, Inventarios Provisionales, 1974.

Conget, José María (1989): Todas las mujeres. Sevilla, Paréntesis Editorial, 2009.

(2013): «Mi vida en los cines», en La mujer que vigila los Vermeer. Valencia, Pre-Textos, pp.83-120.

CuEnCA SANDOVAL, Mario (2007): Boxeo sobre el hielo. (2014): Los dos hemisferios. Barcelona, Seix Barral.

ERICE, Víctor (2007): «Miradas hacia el futuro. Entrevista de Carlos F. Heredero», Cahiers du Cinéma. España, 1 (mayo), p. 11.

FERNÁNDEZ, Luis Miguel (2014): Escritores y televisión durante el franquismo (1956-1975). Salamanca, Ediciones Universidad de Salamanca. 
Tropelías. Revista de Teoría de la Literatura y Literatura Comparada, número extraordinario 2 (2017) 449

Cinefilias al margen de la sala de cine: huellas del cine y la televisión en la novela española...

FERnÁndez Porta, Eloy, (2007): Afterpop. La literatura de la implosión mediática. Córdoba, Berenice.

Goytioslo, Juan (1970): Reivindicación del conde don Julián. Barcelona, Seix Barral.

GuBERN, Román (1995): «El cine después del cine», en Manuel PALACiO y Santos ZunZunEGuI, coords., Historia General del Cine. Volumen XII. El cine en la era del audiovisual. Madrid, Cátedra, pp. 289-309.

JARDIEl Poncela, Enrique (1932): La tournée de Dios. Madrid, Temas de Hoy, 1998.

KIM, Kwang-Hee (2006): El cine y la novelística de Juan Marsé. Madrid, Biblioteca Nueva.

LLAMAZARES, Julio (1994): Escenas de cine mudo. Madrid, Alfaguara.

LYPOVETSKY, Guilles y SERROY, Jean (2009): La pantalla global. Cultura mediática y cine en la era hipermoderna. Madrid, Anagrama.

MARÍ, Jorge (2003): Lecturas espectaculares. El cine en la novela española desde 1970. Madrid, Ediciones Libertarias.

MARÍAS, Javier (2014): Aquí empieza lo malo. Madrid. Alfaguara.

MARSÉ, Berta (2009): «Los Pons-Pons»; «El bebé de Rosmary», en Fantasías animadas. Madrid, Anagrama.

MARSÉ, Juan (1985): El fantasma del cine Roxy. Madrid, Almarabú.

MARTín GAITE, Carmen (1954): «La oficina», en El balneario. Barcelona, Bruguera, 1983. (1958): Entre visillos. Barcelona, Destino, 1984. (1978): El cuarto de atrás. Barcelona, Destino.

MARTÍNEZ DE PISÓN, Ignacio (1996): Carreteras secundarias. Barcelona, Anagrama.

MeRINO, José María (1982): «El niño lobo del cine Mari», en Cuentos del reino secreto. Madrid, Alfaguara, 1994.

MoIX, Terenci (1970/1984): El día que murió Marilyn. Barcelona, Plaza y Janés, 1984.

MORA, Vicente Luis (2011): El lectoespectador. Deslizamientos entre literatura e imagen. Barcelona, Seis Barral.

MuÑoz MolinA, Antonio (1989): Beltenebros. Barcelona, Seix Barral. (2006) El viento de la luna. Barcelona, Seix-Barral. (2015): «Arqueologías del cine», Babelia. El País (12 de septiembre de 2015), p. 8.

ORDÓÑEZ, Marcos (1994): Una vuelta por el Rialto. Barcelona, Anagrama.

PAECH, Anne y PAECH, Joaquim (2002): Gente en el cine. Cine y literatura hablan de Cine. Madrid, Cátedra.

PALACIO, Manuel (2010), «Los intelectuales y la imagen de la televisión cultural, en Antonio ANSÓN et alii, Televisión y literatura en la España de la Transición (1973-1982). Zaragoza, Institución «Fernando el Católico», pp. 11-24.

PEÑA ARDID, Carmen (2016): «La iluminación introspectiva del pasado en La Morte rouge, de Víctor Erice», en Pascale Peyraga, Marion Gautreau, Carmen Peña Ardid y Kepa Sojo Gil, eds., La imagen translúcida en los mundos hispánicos, Éditions Orbis Tertius, pp. 377-397. 
PÉREZ BowIE, José Antonio (2008): Leer el cine. La teoría literaria en la teoría cinematográfica. Salamanaca, Ediciones Universidad de Salamanca.

PUIG, Manuel (1976): El beso de la mujer araña. Barcelona, Seix Barral.

QuintAnA, Ángel (2011): Después del cine. Imagen y realidad en la era digital. Barcelona, Acantilado.

- (2017): «El triunfo del guión frente a la puesta en escena», Caimán. Cuadernos de cine, 59/110 (abril), pp. 14-16.

RIVERA LETELIER, Hernán (2009): La contadora de películas. Madrid, Alfaguara.

RODOREDA, Mercè (1958): «Tarde en el cine», en Veintidós cuentos, en Cuentos. Barcelona, Edhasa, 2008.

RuIZ, Luis Manuel (2010): «Sesión continua», en Sesión continua. Cádiz, Algaida Ediciones.

SÁnCHEZ-Ostiz, Manuel (1989): La gran ilusión. Barcelona, Anagrama.

SANZ, Marta (2012): Un buen detective no se casa jamás. Madrid, Anagrama

— (2013): Daniela Astor y la caja negra. Madrid, Anagrama.

VÁZQUEZ, Ángel (1976): La vida perra de Juanita Narboni. Madrid, Cátedra, 2008.

VIEL, Tanguy (1999): Cinéma. París. Éditions de Minuit.

Vila-Matas, Enrique (2012): El aire de Dylan. Barcelona, Seix Barral.

VIRMAUX, Alain et Odette (1983): Un genre nouveau: le ciné-roman. Paris, Edilig.

ZAFRA, Remedios (2015): Ojos y capital. Bilbao, Consonni.

\section{Filmografía}

Fat City [Fat City, ciudad dorada ] (1972). Dr. John Huston. Estados Unidos.

Ford Apache (1948). Dr. John Ford. Estados Unidos.

Go West [Los hermanos Marx en el oeste] (1940). Dr. Edward Buzell, Estados Unidos.

I Don't Feel at Home in this World Anymore [Ya no me siento a gusto en este mundo] (2017). Dir. Macon Blair. Estados Unidos.

La Morte Rouge (Soliloquio) (2006). Dr. Víctor Erice. España

Mindhunter. Serie TV. Creador: Joe Penhall. Productor: David Fincher. Estados Unidos. Estreno 13 de octubre de 2017.

Remember the Nigth [Recuerdo de una noche] (1940). Dir. Mitchell Leisen. Estados Unidos Sleuth [La huella] (1972). Dir. Joseph Mankiewicz. Reino Unido.

The Man who shot Liberty Valance [El hombre que mató a Liberty Valance] (1962). Dr. John Ford. Estados Unidos.

The Scarlet Claw [La garra escarlata] (1944). Dr. Neill, Roy William. Estados Unidos. Vertigo [Vértigo. De entre los muertos] (1958). Dir. Alfred Hitchcock. Estados Unidos. 